\title{
Spring Cold Injury to Winegrapes and Protection Strategies and Methods
}

\author{
E. Barclay Poling \\ Department of Horticultural Science, NC State University, Campus Box 7609, Raleigh, NC 27695-7609 \\ Additional index words. Chardonnay (Vitis vinifera), postbudbreak stages, radiation frosts, frost/freezes, advective freeze, \\ wind machines, sprinkler irrigation, climate change, supercooling
}

\begin{abstract}
Active frost protection methods may be expensive, but a correctly selected and operated system can provide more consistent crops and improved cash flow in years of potentially damaging cold events at postbudbreak stages of grape development. The selection of an active frost protection system depends on a number of factors, including the prevailing climatic conditions that occur during the spring season at the vineyard location, the costs associated with different frost control systems as well as considerations related to the reliability and relative simplicity of operating the equipment associated with each method. In winegrape production areas in North Carolina, hoar (white) frosts are the predominant cold threat in the postbudbreak period. A wind machine can be a very cost-effective investment on sites that are prone to a damaging frost event in 1 of 5 years or with a higher frequency of occurrence. However, wind machines have less overall usefulness in growing areas where there is also potential for black frosts (a more damaging radiational event than a hoar frost) and frosts/freezes (events with subfreezing temperatures and winds in the range of 2.2 to $4.5 \mathrm{~m} \cdot \mathrm{s}^{-1}$ ). For black frost events, a well-designed overvine sprinkling system can provide nearly $6{ }^{\circ} \mathrm{C}$ protection; sprinkling is also an appropriate management option for frost/freeze events. Windborne freezes are far less common at the postbudbreak stages but represent the most damaging type of cold event that can occur in eastern and midwestern winegrape regions in the United States. Methods that reliably delay budbreak (e.g., dormant oils, evaporative cooling with targeted sprinklers) may represent the best near-term opportunity for growers to decrease or avoid vine injury from freeze events such as the early April Easter freeze of $\mathbf{2 0 0 7}$ that devastated grape vineyards through much of the midwest and southeastern United States.
\end{abstract}

\section{INTRODUCTION AND RATIONALE}

An area of key viticultural concern for the eastern and midwestern regions of the United States has been the need to improve vine winterhardiness and the ability of cold-sensitive Vitis vinifera cultivars to tolerate winter cold damage. A complete discussion of the debilitating effects of winter injury in grapevines, methods to prevent it, and how to respond to it are the subject of a recent bulletin, Winter Injury to Grapevines and Methods of Protection (Zabadal et al., 2007).

The focus of this article is on practical considerations related to what has been traditionally called spring frost protection (Poling, 2007a), but as we learned in early Apr. 2007 , there is potential for enormous damage to grapevines from an ill-timed freeze at the very cold-sensitive postbudbreak stages of shoot development (Warmund and Guinan, 2007). When such a freeze occurs after budbreak, it can result in crop losses and vine injury comparable to a severe midwinter freeze (Martinson and White, 2004, unpublished data, available through Finger Lakes Grape Program, CCE, 417 Liberty Street, Penn Yan, NY). With this in mind and the rationale that it is "easier to troubleshoot problems ahead than undo the damage," this article initially focuses on the full spectrum of cold events that can occur at postbudbreak stages of grapevine shoot development, including radiational frosts of two types (hoar

\footnotetext{
Received for publication 12 Feb. 2008. Accepted for publication 1 July 2008 .

The mention of commercial products, services, or publications is for the reader's convenience and does not constitute endorsement by the North Carolina Cooperative Extension Service or North Carolina State University nor does it imply discrimination against other products, service, or publication not mentioned.
}

frosts and black frosts), frosts/freezes, and freezes. Key characteristics of each type of cold event are described in "Section II. Terminology, Cold Injury, and Types of Spring Cold Events." Potential crop and/or vine damage are discussed as well in Section II.

The third section of the article, "III. Vineyard Site Analysis - A Case Study," examines the worth of investing in a wind machine for a vineyard site in the central piedmont of North Carolina, a region of high "continentality" (Pool, 1997) that is generally considered to be more prone to damaging spring frosts. Of course, there are a number of methods of active protection besides wind machines. The following section of the article, "IV. Choosing an Active Cold Protection Method," is designed to help readers assess the potential benefits and limitations of various conventional methods of active frost protection (wind machines, heaters, helicopters, and overvine sprinkling) as well as less common methods (e.g., chemical sprays).

This article's final section, "V. An Eventbased Management Strategy," is intended to help growers "pull it all together" by discussing the underpinnings of a good cold protection strategy for each of the important types of cold events. The strategy development process is very much controlled by human judgment, and poor decisions with regard to spring cold protection can be very costly. Perhaps that is what prompted an irrigation system distributor at a recent Extension in-service training on spring frost protection, to say "Frost protection is really $80 \%$ the grower and $20 \%$ the equipment."

\section{TERMINOLOGY, COLD INJURY, AND TYPES OF SPRING COLD EVENTS}

\section{A. Terminology issues}

I propose that the subject of spring frost protection should be referred to as spring cold protection to reflect the fact that cold events with subfreezing temperatures and winds of varying speeds (frosts/freezes and freezes) occur in the postbudbreak stage along with more common radiational frost events. Also, although people commonly use the terms frost and freeze interchangeably (Poling, 2007a), in this article, the words frost and freeze describe different types of meteorological events when crops and other plants experience freezing injury [Food and Agriculture Organization of the United Nations (FAO), 2005]. From a cold protection management standpoint, it is especially helpful to refer to frosts and freezes as distinctly different phenomena. A frost is caused by radiational cooling and occurs under clear skies and calm winds (Perry, 1998). The meteorological meaning of freeze is an event that causes heat loss by advection (wind). When a grower receives a weather advisory or warning from the National Weather Service (NWS), it is very helpful to know that a freeze signifies an event that may include a significant amount of wind. The issuance of a freeze warning also indicates to the grower a very dangerous weather event is coming (with subfreezing temperatures and winds exceeding $4.5 \mathrm{~m} \cdot \mathrm{s}^{-1}$ ), and there will be almost no opportunity to apply active cold protection measures (see Table 1 for key differences between strategies and methods of active versus passive control).

A frost/freeze is a third type of meteorological phenomenon in which there is going to be a mix of both radiational cooling and advection. The issuance of a frost/freeze warning by the NWS indicates that there may be some potential to modify environmental conditions in an orchard or vineyard with active protection methods that are unaffected by winds greater than $2.2 \mathrm{~m} \cdot \mathrm{s}^{-1}$. 


\section{B. Cold injury}

As grapes develop from budburst to the various shoot development stages, the plant tissues become more susceptible to cold injury (Johnson and Howell, 1981; Trought et al., 1999). Gardea (1987) evaluated freeze damage of the $V$. vinifera cultivar Pinot noir at six stages of development in spring and found there are important differences between the dormant- enlarged, dormantswollen, and shootburst stages. However, from shoot burst through the second flat-leaf stage, the differences in critical temperatures for freeze injury are in a narrow range of from $-2.2{ }^{\circ} \mathrm{C}$ for shoot burst (budbreak) to $-2.0{ }^{\circ} \mathrm{C}$ for the first flat leaf stage and $-1.7^{\circ} \mathrm{C}$ second flat-leaf stage using an $\mathrm{LD}_{50}$. The critical temperature is the temperature at which injury is likely to occur. The "old" critical temperatures were defined as the temperature that buds (and expanding shoots) could endure without injury for 30 minutes or less. Newer information gives the average temperatures that kill $10 \%, 50 \%$, and $90 \%$ of the buds and shoots (Proebsting, 1978).

However, it can be very difficult (and confusing for a practitioner) to pinpoint critical temperatures and durations required for cold injury in grape tissues at similar stages of development. For example, workers in Oregon (Sugar et al., 2003) noted that "beyond budbreak, damage may occur when developing shoots experience temperatures of $-0.55^{\circ} \mathrm{C}$ or lower for one-half hour or longer." Trought et al. (1999) indicated that new leaves and shoots become susceptible to temperatures only slightly below $0{ }^{\circ} \mathrm{C}$ and that younger tissues with high water content are "killed immediately upon ice crystal formation in tissues." There are also reports that cold injury to grape shoots may not occur under radiational cooling conditions until air temperatures of -3.3 to $-3.8{ }^{\circ} \mathrm{C}$ are reached (Wolf and Boyer, 2003).

Subsequent sections of this article discuss how the exposure to a freezing strain that causes irreversible damage may sometimes occur at temperatures slightly below $0{ }^{\circ} \mathrm{C}$ (hoar frost), and in other conditions, supercooling may occur (when grape shoots have the ability to drop below their "normal" freezing temperature and not freeze). However, as a result of the difficulty (at this time) of determining whether grape shoots are supercooling in vineyard conditions, it is a safer strategy to adopt the higher end critical temperature reported for budburst of $-2.2{ }^{\circ} \mathrm{C}$ by Perry (1998) in North Carolina for 50\% kill. Also, for early shoot stages, a critical tissue temperature of just below $0{ }^{\circ} \mathrm{C}$ may be most appropriate, especially under hoar (white) frost conditions for reasons that will be explained in this article's final section, "V. An Event-based Management Strategy."

The important goal for the vineyard manager is to keep tender shoots above the point at which a freezing strain may occur that can result in "malfunction or death of plant cells" (FAO, 2005). Each of the cold events discussed in this next section are capable of causing irreversible injury. On thawing, cold- damaged grape shoots are observed to lose turgor, completely darken, and become water-soaked. Also, completely limp grape tissues may be observed within a few hours after the cold event (Sugar et al., 2003).

\section{Types of spring cold events}

1. Radiational frosts (hoar frosts and black frosts). These types of cold events are caused by longwave radiational losses of heat from the ground and solid objects (like a grape shoot) and occur when clear skies and calm winds allow an inversion to develop and temperatures near the surface drop below $0{ }^{\circ} \mathrm{C}$ (Perry, 1998). With an inversion, the temperature is actually increasing with altitude to the top of an air layer (opposite to the daytime condition where air temperature decreases with height). Figure 1 shows the important effect of vineyard site topography on air temperature stratification. Note the collection of colder air at the bottom of the slope. Cold air flows downhill, much like a liquid, during a radiational cooling period. In the spring (and fall), there will be frequent radiational frosts in lower elevation areas like a river or creek bottom; these areas are called often called "frost pockets." Vineyards located at higher elevations, relative to surrounding topography, will be affected by fewer radiational frosts. The most favorable grape-growing sites are located in "thermal belts" (Hurt, 1923), also called "thermo- belts" (Dami et al., 2005). These are areas where significant variations in local elevation generate strong inversions for relatively frost-free apple, peach, and grape production.

In North Carolina, the "thickness" of the inversion layer will generally vary from 10 to $60 \mathrm{~m}$ (Perry, 1994). The warm air in an inversion is critical to the operation of wind machines and helicopters, which depend on this source of heat on vineyard sites where active protection methods are needed (Table 1). A temperature inversion cannot form if winds exceed $1.8 \mathrm{~m} \cdot \mathrm{s}^{-1}$ (Fraser et al., 2008).

If a tender plant part such as a rapidly growing grape shoot is killed as a result of a radiational frost, secondary shoots soon break bud and produce sufficient foliage to maintain vine health. Even a second frost can be compensated for by growth of latent buds on the vine (Wolf and Poling, 1995). However, secondary shoots of $V$. vinifera cultivars such as 'Chardonnay' typically have less than half the fruiting potential of primary shoots, and latent "base" buds usually have no preformed fruit clusters (Wolf and Poling, 1995).

Important differences between a hoar frost and a black frost. The most common type of radiational cooling event is a hoar frost. Hoar frosts occur when atmospheric

Table 1. Defining active control methods.

Active frost control differs from passive control strategies and methods in several important ways:

1) Energy use. Active control methods include energy intensive practices (vineyard heating with fuel, overvine sprinkling with water, and so on) that are used during the cold event to replace natural energy or heat losses from the vine (Snyder, 2001).

2) Direct versus indirect method. Active control strategies rely on direct frost protection methods (e.g., wind machines, heaters, overvine sprinkling) and involve active control against a cold event (Westwood, 1978). Passive control or protection involves indirect practices (e.g., site selection, variety selection, and cultural practices like double pruning or sprinkling to delay budbreak) that cause the plant to be less susceptible to cold injury or decrease the probability or severity of radiation frosts (Evans, 2000).

3) Time of implementation. Active control strategies and methods must be implemented just before and/ or during the cold event to counteract an immediate threat of a radiation frost or frost/freeze. Passive protection includes strategies and practices that are generally done well ahead of cold events, like delayed pruning.

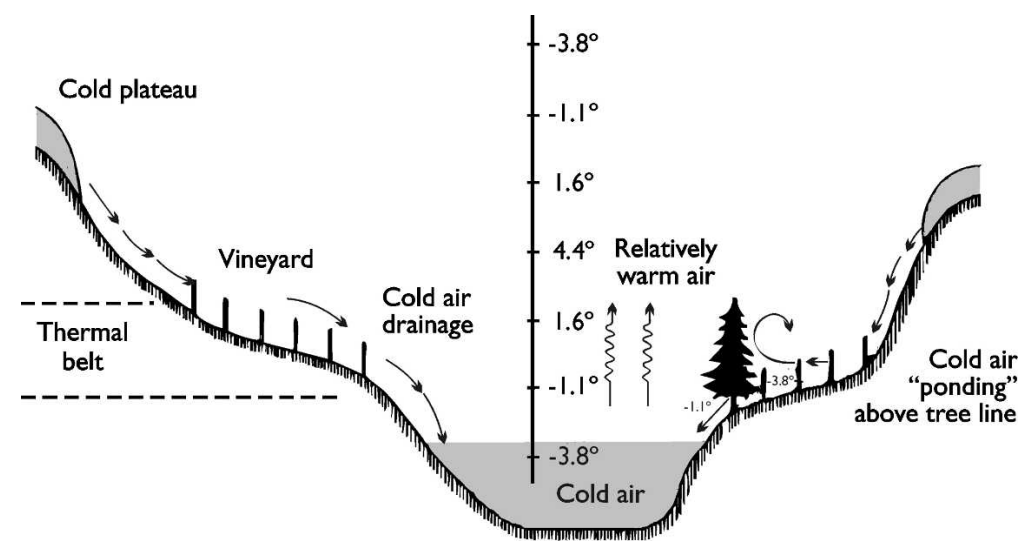

Fig. 1. Effect of vineyard site topography on air temperature stratification during a radiational cooling period characterized by calm winds and clear skies. 
water vapor freezes in small crystals on solid surfaces (sublimation), also called a white frost for the white layer of ice crystals formed on the ground, grass blades, twigs, and young grape shoots. The dew point (DP) temperature is unquestionably one of the most valuable pieces of information you get as a subscriber to an advance recommended weather forecast service to determine whether conditions are favorable for hoar frost. The DP is defined as the temperature at which water vapor in the air becomes saturated and then condenses as dew, fog, or frost (Westwood, 1978). A relatively high DP indicates that the lower atmosphere is moist and that there may be potential for a hoar frost. A relatively low DP temperature indicates drier air, and in this scenario, there is potential for a second type of radiational frost called a black frost, which is potentially a much more serious cold event than a hoar frost. A recent example of this type of event was a deadly black frost in 2006 that caused havoc for grape growers across South Australia's drought-hit southeast regions, wiping $\$ 100$ million off the value of their 2007 vintage (Sproull, 2006).

These events are distinct from hoar frost because few or no ice crystals form on plant surfaces in a black frost because the lower atmosphere is essentially too dry. Thus, the grape grower who depends on seeing evidence of "frost" (ice crystals) before starting countermeasures (for cold protection) can easily be fooled by the "invisibility" of a black frost.

In a black frost, we generally assume the DP temperature is below the critical temperature (Howell, 1998). However, then we are also assuming that the critical temperature of an emerged grape shoot is likely in the range of 0 to $-2.2{ }^{\circ} \mathrm{C}$. It is important to note what Wolf and Boyer (2003) in Virginia have observed: "Grape shoots are very susceptible to freeze injury if temperatures dip below $32{ }^{\circ} \mathrm{F}\left(0^{\circ} \mathrm{C}\right)$. Under very dry air conditions, the injury may not occur until temperatures reach $25^{\circ} \mathrm{F}\left(-3.3{ }^{\circ} \mathrm{C}\right)$ or $26^{\circ} \mathrm{F}\left(-3.8^{\circ} \mathrm{C}\right)$, but shoots would rarely survive lower air temperatures."

Natural factors that will help keep ice crystals from forming include winds of greater than $2.2 \mathrm{~m} \cdot \mathrm{s}^{-1}$. Cloud covers and potentially drier soil conditions (Sugar et al., 2003) are other natural factors that keep ice crystals from forming.

2. Freezes. When the NWS issues a warning for a freeze, this means that the potential exists for a very dangerous weather event with subfreezing temperatures and winds exceeding $4.5 \mathrm{~m} \cdot \mathrm{s}^{-1}$ (Perry, 1998). With freeze events, it is important to note that these types of events are associated with the passage of large frontal systems of very cold air over an entire region, and it is virtually impossible to find sites in an affected region that are unaffected by windborne freeze events, except perhaps lowerlying river bottom-type areas that are protected from the winds. Clouds may be present in a freeze. The thickness of the cold air layer ranges from 150 to $1500 \mathrm{~m}$ or more (Perry, 1994).

The destructive potential, and ultimate economic impact, of an advective freeze on a grape crop in the postbudbreak stages of shoot development can be "catastrophic" (see Fig. 2). The total freeze-related agricultural losses from the Apr. 2007 Easter freeze are now estimated to have exceeded \$2 billion (Wolf, 2007). In North Carolina, 'Chardonnay' shoots had reached the fifth leaf stage, and in vineyards with temperatures of $-5^{\circ} \mathrm{C}$ or below, not only were all primary shoots killed, but phloem, cambium, and even xylem damage occurred (Spayd, 2007). Thus, the effects of the 2007 Easter freeze did more than significantly reduce the grape harvest for early budbreak vinifera cultivars such as Chardonnay. It has also contributed to many problems and challenges that are more normally associated with severe winter injury in cold-tender cultivars of all grape species, including most vinifera cultivars as well as interspecific hybrids such as Chardonel. Figure 3 shows crown gall disease development on the trunk of a Chardonel vine injured in Missouri.

3. Frost/freezes. In the mountains of western North Carolina, there are numerous vineyard production sites that have both significant radiation frost problems in the spring after budbreak as well as difficulties with what is termed a frost/freeze (Perry, 1998). A frost/freeze combines characteristics of both a radiational frost and a freeze. As defined by the NWS, a frost/freeze warning indicates the potential for a cold event with winds of less than $4.5 \mathrm{~m} \cdot \mathrm{s}^{-1}$ and temperatures lower than $0{ }^{\circ} \mathrm{C}$. Although the NWS does not set an official lower limit for the wind speeds associated with a frost/freeze, it might be inferred that the winds associated with a frost/freeze are in the range of 2.2 to $4.5 \mathrm{~m} \cdot \mathrm{s}^{-1}$ because Perry (1998) has defined a radiation frost event as having winds of less than of $2.2 \mathrm{~m} \cdot \mathrm{s}^{-1}$. Crop losses from a frost/ freeze event can be quite extensive because these subfreezing events are typically very long in duration (often greater than $10 \mathrm{~h}$ ), and crop protection is made very difficult by sustained winds of more than $2.2 \mathrm{~m} \cdot \mathrm{s}^{-1}$. There are relatively few control options for managing more severe events such as a frost/freeze in the postbudbreak period except for overvine sprinkling (see "Section IV, and Section V.B-2").

\section{VINEYARD SITE ANALYSIS- A CASE STUDY}

The grower's strategy for managing damaging radiational frost events, the most common type of spring cold event at the postbudbreak development stages, can logically begin with a careful analysis of the risk of frost damage associated with a potential new vineyard site or sites. Some sites may be so frost-prone that the best decision is to pull up and walk away (Poling, 2007a). In other cases, a site may be purchased and developed with the realization that it does have some risk of frost damage and that active control measures will be required.

Exploring the range of possible cold protection options is important, but it is also critical to remember that "Profitability ultimately determines whether frost protection techniques can be used" (Trought et al., 1999). To help decide whether an investment in a wind machine, for example, may be an economical investment for a 'Chardonnay'

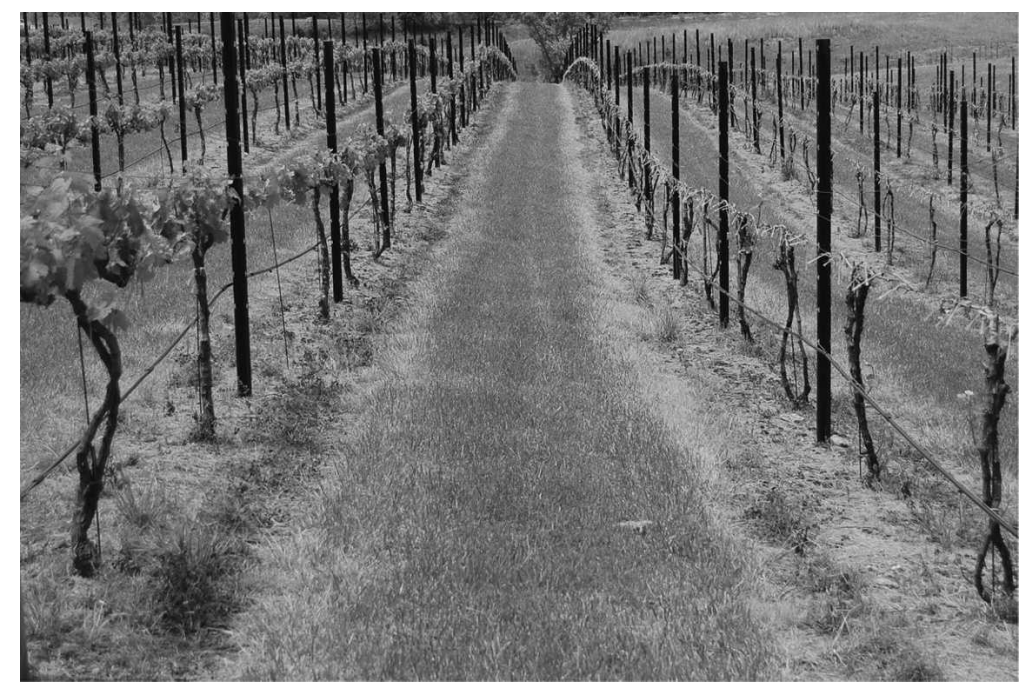

Fig. 2. A historic freeze in early Apr. 2007 (also known as the Easter freeze) occurred from the central and southern plains into the midwest and southeast after the nation's second warmest March on record. The freeze was particularly devastating to early-breaking cultivars. The row of 'Chardonnay' vines (right) were at approximately the fifth leaf stage of shoot development when the freeze hit 7 to 8 Apr. 2007, and all growing shoots and buds that had not broken that were associated with actively growing shoots were killed when temperatures dropped below $-5.0^{\circ} \mathrm{C}$. Other $V$. vinifera cultivars like 'Cabernet Sauvignon' (left) had substantially less injury because of delayed bud. (Photo by Sara Spayd, Professor and Extension Viticulturist, NC State University.) 
winegrape producer in the rolling piedmont region of North Carolina, we have adapted an approach used in New Zealand for assessing the frost hazard of potential vineyard sites (Trought et al., 1999) and have coupled this with an investment analysis. To illustrate this approach with a case example, we evaluated the probability of frost damage for the Upper Piedmont Research Station, Reidsville, NC (elevation $265 \mathrm{~m}$, latitude $36^{\circ} 23^{\prime} \mathrm{N}$, longitude $79^{\circ} 42^{\prime} \mathrm{W}$ ) using temperature records from 1902 through 2005 and compared this information with the average dates of budbreak and early shoot development for 'Chardonnay' vines in a research vineyard planted in 2001. Unfortunately, only 3 years of data $(2003,2004,2005)$ were available for estimating an average week of budbreak (15 Apr.), 1- to 2-inch shoot stages (22 Apr.), 10 -inch shoots (5 May), and prebloom (15 May). Models can also be used to predict budbreak, and these have been developed by Moncur et al. (1989) and have been used in New Zealand (Trought et al., 1999).

Longer-term climatic records (30+ years) are preferred for assessing the potential for frost on possible vineyard sites, but for locations where longer-term records are unavailable, direct temperature surveys for at least one season and preferably two are recommended (Poling, 2007a). Frost events during critical growth periods in early spring can be strongly influenced by a site's local topography and possible barriers to air drainage, and thus there is a good reason to evaluate both longer-term climatic records as well as conduct direct temperature surveys.

The results of our frost probability estimates for this location (Reidsville, NC) are shown in Table 2. For the week of 15 to 21 Apr., which has been observed to be, on average, the week of budbreak for 'Chardonnay' (Poling, 2007a), there is only a 5.2\% risk of cold injury using an air temperature threshold of $-2.2{ }^{\circ} \mathrm{C}$ for the shootburst stage. Also, in the week of 22 to 29 Apr. when Chardonnay vines typically reach the more cold-sensitive 2.54 - to 5.08 -cm shoot stage, there is potentially a $5.7 \%$ risk of injury using a threshold of $0{ }^{\circ} \mathrm{C}$ (Poling, 2007a; Trought et al., 1999).

Can a wind machine be profitable? For the Reidsville, NC, vineyard site, an approximate $5 \%$ risk of frost damage in either the week of budbreak (15 to 21 Apr.) or early shoot development (21 to 29 Apr.) can be interpreted as a low-risk situation, and our investment analysis showed that a $5 \%$ probability of frost injury would not justify purchase of a new wind machine (Table 3 ). If this had been a colder site, however, with say a $20 \%$ risk of frost ( 1 in 5 years), then a wind machine could add $\$ 446 /$ ha in net returns or more depending on the frost probability (Table 3 ).

Practical considerations rule out irrigation. A grower must consider a number of economic as well as practical considerations when deciding whether to invest in an active cold protection system or method, and difficult tradeoffs are generally involved.

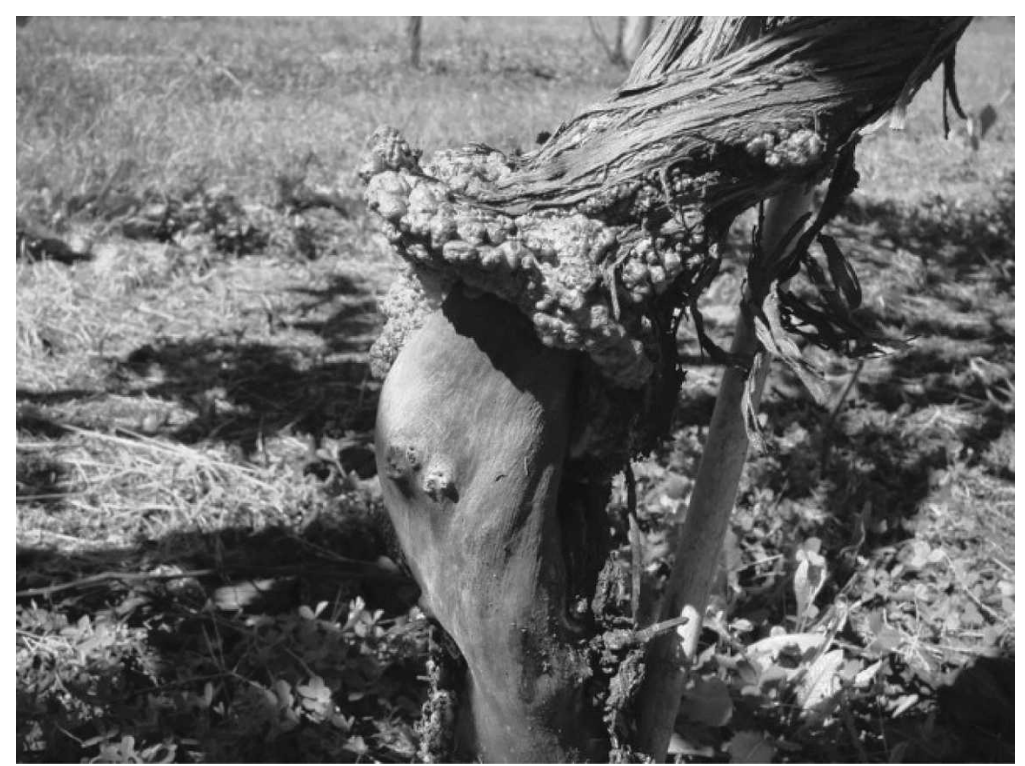

Fig. 3. Photo taken on 11 Sept. 2007 from commercial vineyard in Missouri showing Easter freeze 2007 trunk injury on Chardonel (an interspecific hybrid). Chardonel vines recovered from the freeze only to have crown gall show up mid to late summer. Crown gall is now a widespread problem in vineyards all over the states of Missouri and Arkansas as a result of this freeze. (Photo by Andy Allen, Extension Associate-Viticulturist, Institute for Continental Climate Viticulture, University of MissouriColumbia, Columbia, MO.)

Table 2. Weekly frost probabilities for Piedmont vineyard site (Reidsville, NC) using temperature records from 1902 through $2005^{z}$

\begin{tabular}{lcccc}
\hline $\begin{array}{l}\text { Temp } \\
\text { threshold } \\
\left({ }^{\circ} \mathrm{C}\right)\end{array}$ & $\begin{array}{c}\text { Dormant buds } \\
\text { swollen } \\
\text { 8 to 14 Apr. }\end{array}$ & $\begin{array}{c}\text { Budbreak or } \\
\text { shootburst } \\
\text { 15 to 21 Apr. }\end{array}$ & $\begin{array}{c}\text { 1- to 2-inch or } \\
\text { 2.54- to 5.08-cm } \\
\text { shoot stage 22 to 29 Apr. }\end{array}$ & $\begin{array}{c}\text { Shoots elongated } \\
\text { to 10 inches }(25.4 \mathrm{~cm}) \\
\text { 30 Apr. to 5 May }\end{array}$ \\
\hline 0 & 53.4 & 21.0 & 5.7 & 2.6 \\
-0.55 & 34.0 & 16.1 & 3.4 & 0 \\
-1.11 & 23.1 & 12.5 & 2.1 & 0 \\
-1.66 & 17.1 & 10.6 & 1.6 & 0 \\
-2.22 & 9.9 & 5.2 & 0 & 0 \\
\hline
\end{tabular}

${ }^{z}$ The daily probabilities of frost occurrence in the month of April and May were first calculated using Reidsville temperature records from 1902 through 2005. Then these data were "smoothed" using a 5 -d moving average. The smoothed daily probabilities of frost occurrence [at set temperatures of $0{ }^{\circ} \mathrm{C}$ $\left(32^{\circ} \mathrm{F}\right),-0.55^{\circ} \mathrm{C}\left(31^{\circ} \mathrm{F}\right),-1.11^{\circ} \mathrm{C}\left(30^{\circ} \mathrm{F}\right),-1.66^{\circ} \mathrm{C}\left(29^{\circ} \mathrm{F}\right)$, and $\left.-2.22^{\circ} \mathrm{C}\left(28^{\circ} \mathrm{F}\right)\right]$ were then summed to generate the weekly frost probability estimates shown. Daily smoothed frost probability estimates provided courtesy of North Carolina State Climate Office.

Table 3. Average net returns of vineyards with different probabilities of frost damage (assumes $40 \mathrm{~h}$ of wind machine use in years with frost $)^{2}$.

\begin{tabular}{lccccc}
\hline \multirow{2}{*}{$\begin{array}{l}\text { Probability of frost } \\
\text { damage (\%) }\end{array}$} & \multicolumn{2}{c}{10 -yr avg net returns (\$/ha) } & & \multicolumn{2}{c}{ Difference in avg net returns } \\
\cline { 2 - 3 } & $\begin{array}{l}\text { Vineyard with } \\
\text { wind machine }\end{array}$ & $\begin{array}{c}\text { Vineyard without } \\
\text { wind machine }\end{array}$ & & \$/ha & $\begin{array}{c}\text { \$/4.047 ha } \\
\text { vineyard }\end{array}$ \\
\hline 0 & 1,984 & 2,711 & -726 & $-7,264$ \\
10 & 1,928 & 2,068 & & -140 & $-1,410$ \\
20 & 1,872 & 1,426 & & 446 & 4,463 \\
30 & 1,838 & 783 & & 1,033 & 10,327 \\
40 & 1,760 & 141 & & 1,619 & 16,191 \\
50 & 1,704 & -502 & & 2,206 & 22,055 \\
60 & 1,648 & $-1,144$ & & 2,792 & 27,919 \\
70 & 1,592 & $-1,786$ & & 3,378 & 33,783 \\
80 & 1,536 & $-2,318$ & & 3,965 & 39,647 \\
90 & 1,480 & $-3,071$ & & 4,551 & 45,511 \\
100 & 1,424 & $-3,714$ & & 5,137 & 51,375 \\
\hline
\end{tabular}

${ }^{2}$ Estimated costs of installation and use of a wind machine in a 4.047-ha vineyard; initial equipment cost $\$ 28,000$ per unit; annual total ownership (fixed) cost $\$ 726 /$ ha; operating costs $\$ 5.36$ per hour; and labor costs $\$ 25.94$ per hour.

${ }^{y}$ Assumes $50 \%$ crop loss; at a price per ton of $\$ 1400$ (for 'Chardonnay'), a $4.94 \mathrm{Mt} \cdot \mathrm{ha}^{-1}$ will generate only $\$ 6918$, which is barely enough revenue to cover annual operating expenses of $\$ 6609 /$ ha [Safley, C.D., C.E. Carpio, and E.B. Poling. 2007. Cost and investment analysis of Chardonnay (Vitis vinifera) winegrapes in North Carolina. The North Carolina winegrape grower's guide. North Carolina Coop. Ext. Serv., NC State University, Raleigh, AG-535.]. 
Table 4. Relative effectiveness of passive, active frost, and active frost/freeze protection methods under different cold event scenarios.

\begin{tabular}{|c|c|c|c|c|}
\hline Method & $\begin{array}{l}\text { Radiational } \\
\text { hoar frost; temp } \\
-2.2 \text { to } 2.2^{\circ} \mathrm{C}\end{array}$ & $\begin{array}{l}\text { Radiational black } \\
\text { frost and/or weak } \\
\text { inversion; temp } \\
\text { below }-2.2^{\circ} \mathrm{C}\end{array}$ & $\begin{array}{l}\text { Frost } / \text { freeze and } \\
\text { temp below }-2.2^{\circ} \mathrm{C} \\
\text { (winds of } 2.2 \mathrm{~m} \cdot \mathrm{s}^{-1} \\
\text { to } 4.5 \mathrm{~m} \cdot \mathrm{s}^{-1} \text { ) }\end{array}$ & Comments \\
\hline $\begin{array}{l}\text { Good site selection } \\
\text { (passive) }\end{array}$ & Highly effective & Effective & Limited effectiveness & $\begin{array}{l}\text { Locations with good air drainage; visualize } \\
\text { air flow/and evaluate frost climatology. }\end{array}$ \\
\hline Wind machine & Highly effective & $\begin{array}{l}\text { Limited } \\
\text { effectiveness }\end{array}$ & $\begin{array}{l}\text { Ineffective, potentially } \\
\text { damaging }\end{array}$ & $\begin{array}{l}\text { Do not use if winds are greater } \\
\text { than } 1.8 \mathrm{~m} \cdot \mathrm{s}^{-1}\end{array}$ \\
\hline $\begin{array}{l}\text { Wind machine plus } \\
\text { heaters }\end{array}$ & Not applicable & Effective & Limited effectiveness & $\begin{array}{l}\text { Can be effective in black frost, weak } \\
\text { inversion, or frost/freeze; merits further } \\
\text { attention; not needed in a hoar frost }\end{array}$ \\
\hline $\begin{array}{l}\text { Wind machine plus } \\
\text { helicopter }\end{array}$ & Not applicable & Highly effective & Ineffective & $\begin{array}{l}\text { Useful when inversion ceiling is high; } \\
\text { not needed in a hoar frost }\end{array}$ \\
\hline Overvine sprinkling & Highly effective & Highly effective & Effective & Incorrect use can cause greater damage \\
\hline Helicopter & Highly effective & Effective & $\begin{array}{l}\text { Ineffective, potentially } \\
\text { damaging }\end{array}$ & $\begin{array}{l}\text { Very high costs per hour, greater than } \\
\$ 2000 \text { per hour in } 2006\end{array}$ \\
\hline Heaters & Highly effective & Effective & Effective & $\begin{array}{l}\text { Very limited use in North Carolina } \\
\text { vineyards as a result of high cost of fuel }\end{array}$ \\
\hline
\end{tabular}

Although overvine sprinkling systems offer the "highest level of protection of any available system" (Evans, 2000), they are frequently not practical because of the substantial water resources needed for this type of protection as discussed in "IV. Choosing an Active Cold Protection Method." Water availability problems are one of the main reasons that none of the vineyard operations in the piedmont region of North Carolina use overvine sprinkling.

\section{CHOOSING AN ACTIVE COLD PROTECTION METHOD}

One important criterion in selecting an active method of frost protection is to match the cold protection method/system with the prevailing type or dominant character of an expected frost (cold) event(s) in a specific region and location (Evans, 2000). In making this "match," a number of tradeoffs are typically involved. As the first column in Table 4 shows, wind machines, heaters, overvine sprinklers, and helicopters all may protect against hoar frost conditions. However, the method of active frost protection you select matters a great deal when it comes to either a black frost or frost/freeze condition.

\section{A. Wind machines}

In North Carolina's Piedmont area, wind machines are the preferred method of cold protection in the postbudbreak period for several reasons:

1. Wind machines are effective for controlling radiational hoar frost events (this region's prevalent type of cold event).

2. A wind machine can be justified on the basis of higher average net returns on sites where there is a probability of frost injury one in 5 years (see the previous section) and can potentially improve vine health (Evans, 2000).

3. Their hourly operating costs are still substantially below return stack oil heaters and standard propane heaters.
4. They do not require substantial water resources as is the case with overvine sprinkling.

Also, wind machines do not cause waterlogging of the vineyard soil with subsequent plant health problems, which is a real potential problem with sprinkler irrigation on heavier soils that are not free-draining.

Some important limitations to wind machine use, however, include the following:

1. The minimum size vineyard that justifies a wind machine investment is 2.8 to 4.0 ha (for each wind machine).

2. Wind machine operating costs are higher than for overvine sprinkling, and in 2005 costs, a fully installed wind machine was $\approx \$ 7000 /$ ha (assuming 4 ha of coverage per machine).

3. Wind machines produce very loud noises, and any nearby neighbors may object strongly to their use (Ker, 2007).

4. Persistent winds in the range of 1.8 $\mathrm{m} \cdot \mathrm{s}^{-1}$ will prevent the formation of an inversion, so wind machines and helicopters will not provide sufficient protection under relatively windy conditions (Table 4).

Wind machines work well under hoar frost conditions (Table 4). However, a grower will need an additional protection method in colder temperatures that are associated with a black frost in which minimum temperatures may be too cold for wind machine protection. In the latter situation, some supplemental heating would be required if there is a real probability of experiencing temperature minimums below $-2.2{ }^{\circ} \mathrm{C}$.

\section{B. Heaters}

Either heaters or a helicopter can significantly "boost" the effective protection of a wind machine in colder radiational frost conditions (Table 4). Perry (2001) has indicated that heaters may be used to supplement wind machines when extra heat is needed during nights in which temperatures may fall below the capacity of wind machine pro- tection. Although burning these fuels (e.g., diesel) as the sole means of frost protection is prohibitively expensive, it may be worth investigating the use of a limited number of heaters arrayed around the perimeter of the vineyard and in portions of the vineyard farthest from the wind machines under colder radiational frost conditions. Air pollution by smoke can be a significant problem, and the use of oil-fired heaters is banned in many areas. At this time, none of the vineyards with wind machines in North Carolina's central and western Piedmont areas are using supplemental heaters.

\section{Helicopters}

Helicopters are an expensive variation of wind machines but they can be considerably more effective than a wind machine because they can adjust to the height of an inversion machines (Evans, 2000). A single large helicopter can protect more than 20 ha (HeloAir, Inc., Richmond, VA, personal communication). Because of their great expense (hourly costs may range from $\$ 2000$ to $\$ 4000 /$ ha), helicopters are only used when a black frost is forecast. At best, the experience with wind machines in North Carolina indicates that they provide protection down to $-2.2{ }^{\circ} \mathrm{C}$ (Matt Chobanian, Vineyard Manager, Childress Vineyards, Lexington, NC, personal communication).

\section{Overvine sprinklers}

In vineyards subject to black frosts and frost/freezes, overvine sprinkling can be especially effective. In a recent black frost (not freeze) episode in eastern North Carolina, 'Carlos' muscadine ( $V$. rotundifolia) was in its first to fourth leaf development stage when minimum temperatures of -4.4 to $-8.8{ }^{\circ} \mathrm{C}$ occurred Easter morning ( 8 Apr. 2007), and this was clearly a case in which wind machine protection would not have helped. In fact, damage to the wind machine itself can be expected in temperatures this cold. However, even with expected minimums down to $-5{ }^{\circ} \mathrm{C}$ or perhaps $-6{ }^{\circ} \mathrm{C}$, successful protection with sprinkling could have been achieved with full-cover overvine 
sprinklers (Biltmore Estates and Winery, personal communication). If the vineyard site is highly prone to black frosts and frosts/ freezes, one of the real advantages of overvine sprinkling is its very reasonable cost for operating. Evans (2000) has reported that overvine sprinkling was $\approx 12 \%$ of the cost per hour of wind machines (requiring fuel) and only $\approx 4 \%$ of the hourly cost to operate a return-stack oil heater system $(\approx 100$ heaters/ha).

Some of the reasons that overvine sprinkling has not been popular with vineyard operators in North Carolina include cost and water:

1. The cost of materials, installation, and development (usually including a pond);

2. Not having enough water resources to safely provide three consecutive frost/ freeze nights of protection $(\approx 960,000$ L of water/ha);

3. Complexity of operation and high risk of vine damage if the system fails in the middle of the night; and

4. Although sprinkler irrigation offers the highest level of protection of any single frost control system, their fixed-rate design delivers more protection than generally necessary (Perry, 1998). They can only be turned on or off, so you cannot vary the irrigation rate. This contributes to overwatering, which can waterlog soils, leach fertilizers, and may increase disease pressures.

If the grower decides to invest in overvine sprinklers for radiation frost and frost/freeze control in the vineyard, it is much more convenient to install the system before the vineyard is planted than to add it to an existing vineyard.

Overvine sprinkling is quite important in some winegrape areas of the world (Jackson, 2000) such as the inland central Ontago region in New Zealand (Wooing Tree Vineyard, 2008). However, in North Carolina, there is only one vineyard in the mountains (near Asheville) that is using this method of active protection (Poling, 2007a).

\section{Less conventional methods}

Less conventional nonmechanical methods of active frost protection (not identified in Table 4) include chemical sprays. Chemical sprays made just before a cold event such as the application of hydrophobic particle film (Wisniewski, 2007) would be considered an active protection method. A few vineyards in North Carolina are using special foliar nutrient sprays to change the freezing point of the plant tissue, but more research on this technique is needed (Poling, 2007a). To the author's knowledge, biodegradable foam has been tried successfully on strawberries and vegetables in Florida, but there has been no reported experience on grapes. Striegler (2007) has observed that the use of frostprotectant materials that inhibit ice nucleation bacteria (Lindemann and Suslow, 1987) have generally not been found to be effective.
A few vineyards in North Carolina are using special foliar nutrient sprays to change the freezing point of the plant tissue, but more research on this technique is needed. In trials conducted in Oregon (Sugar et al., 2003), little or no frost protection was obtained from treating vines with substances that are supposed to depress the freezing point or inhibit bacteria that can serve as nucleators for ice formation. USDA/ARS researchers are now working with a prototype film called "Surround" that protects plants from frost damage by creating a barrier between ice crystals and plants' tender tissues that could be worth investigating.

Foggers. Fog lines that use high-pressure lines and nozzles to make fog droplets have been reported to provide excellent protection under calm conditions (Evans, 2000). Little water is deposited, minimizing the potential for ice-load damage (a concern with overvine sprinkling). However, containing and/or controlling the drift of fogs and potential safety and liability problems (if fogs cross a road) are factors that may seriously limit the usefulness of fogging systems (Evans, 2000). Currently, the author is not aware of any foggers being used in North Carolina vineyards or anywhere in the eastern United States.

\section{AN EVENT-BASED MANAGEMENT STRATEGY}

"The grower must know the kind of frost confronting him each time the frost alarm rings." (From the milestone extension bulletin, Frost and Frost Control in Washington Orchards (Ballard and Proebsting, 1981).

Thus far, this article has provided quite a bit of information on the characteristics of cold events and the different active protection options. The purpose of this final section is to discuss the management of different types of cold events. To be a good cold protection strategist, you do not need a library stuffed with 8000 pages of technical information on everything that has ever been written on the whole subject of low temperature injury in fruit crops. However, you do need to be good at something they call in the medical field "differential diagnosis." This is a process whereby the subject, in this case the cold event threatening your vineyard, is examined for its key characteristics using several weather forecast products (minimum temperatures, wind speeds, cloud cover, and dew point temperatures) to assist in making a correct "diagnosis" of the cold event. Once you have diagnosed the event, the information in Table 4 is particularly useful for evaluating the most effective control methods. Questions about when to start up protection measures, how to monitor the operation of a cold protection system, and when it is safe to shut down are most effectively addressed based on the event type.

For the management of each type of cold event, important cold damage mechanisms are discussed as well as some general operating guidelines for using wind machines and overvine sprinkling (where applicable), because these are currently the two most popular methods of active spring cold protection in the United States and Canada.

\section{A. Event diagnosis}

You do not have to be caught "off guard" by a sudden cold event provided that you are a proactive vineyard manager and routinely take full advantage of regional and localized weather forecast products and key information on wind speeds, dew point temperatures, minimum temperatures, and durations below freezing. These reports may also provide helpful information on percent cloud cover, inversion strength, and possibly hourly wet bulb temperatures, which are going to be needed if you plan to use an overvine sprinkling system.

Figure 4 shows an event "decision tree" that begins at the stage where the grower first receives a forecast of a potentially threatening cold event, and then by answering a series of important questions, a grower can make an informed judgment about the type of cold event he or she is probably confronting. Event diagnosis is a very iterative process. You often do not know exactly what type of event you are dealing with until several hours before its arrival. Nonetheless, you can start formulating "an idea" of what you may be encountering by examining $72-\mathrm{h}, 48-\mathrm{h}$, and $24-\mathrm{h}$ advance weather forecasts. The various steps in the decision tree are further explained in the subsequent text.

Step 1. Observe minimum temperature forecast.

If there is potential for minimum air temperatures in the vineyard of less than $1.1^{\circ} \mathrm{C}$, be on ALERT for the potential of a hoar frost. [A weather forecast indicating that minimum temperatures are not "expected" to go below freezing $\left(0^{\circ} \mathrm{C}\right)$ but may have temperatures below $1.1{ }^{\circ} \mathrm{C}$ needs to be carefully monitored for the real potential of a damaging hoar frost if other conditions are also favorable (calm winds, clear skies, dew point temperatures in the range of 1.1 to $\left.2.2{ }^{\circ} \mathrm{C}\right)$.]

If there is a forecast for subfreezing temperatures, then go to Step 2 (winds).

\section{Step 2. Evaluate wind speed products.}

If the forecast is for winds greater than 4.5 $\mathrm{m} \cdot \mathrm{s}^{-1}$ (and subfreezing temperatures), you are dealing with a freeze and no active control measures are recommended. If the forecast is for winds in the range of 2.2 to $4.5 \mathrm{~m} \cdot \mathrm{s}^{-1}$ (and subfreezing temperatures), you are dealing with a frost/freeze and relatively few methods of active cold protection apply (see Table 4).

If the forecast is for calm winds of less than $2.2 \mathrm{~m} \cdot \mathrm{s}^{-1}$ and temperatures near the ground surface are below $0{ }^{\circ} \mathrm{C}$, you are dealing with some type of radiational cooling event (go to Step 3 to determine which kind). 


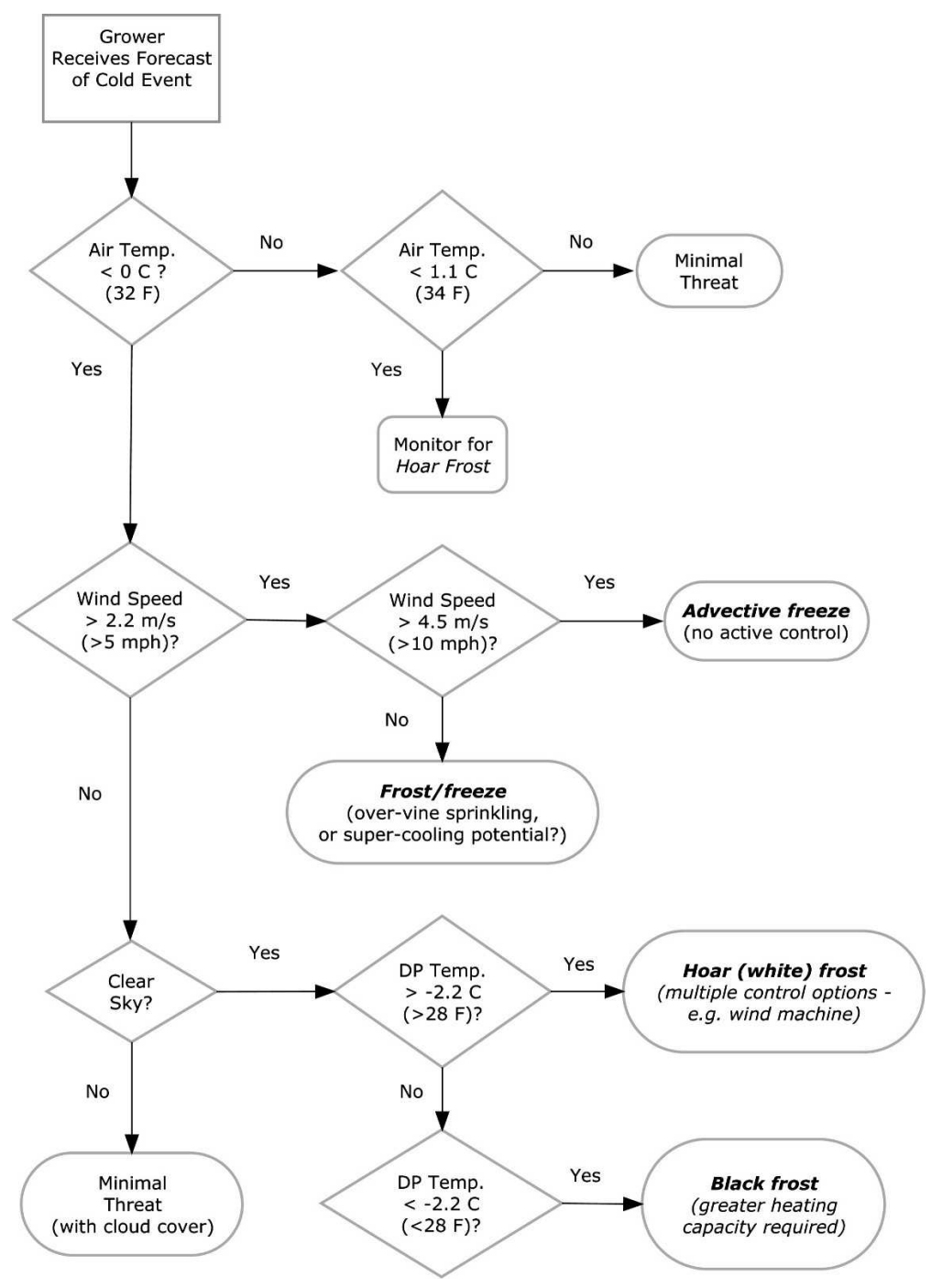

Fig. 4. Cold event diagnosis.

Step 3. Evaluate atmospheric humidity with dew point temperature.

A relatively high DP (greater than $-2.2{ }^{\circ} \mathrm{C}$ ) indicates the potential for hoar frost. Go to the next section, "B.3 Event Management for Hoar Frosts," for control recommendations.

A relatively low DP temperature indicates drier air and thus the potential for a killing black frost. Go to the next section, "B.4 Event Management for Black Frosts," for control recommendations

\section{B. Event management}

1. Advective freeze events. Attempts to directly protect swollen buds or young grape shoots by modifying the environment with overvine sprinkling, heating, or wind machine use will not be effective when there is a large-scale incursion of cold air into the region with a well-mixed, windy atmosphere. Thus, the best active strategy in an advective freeze is to "do nothing" when sustained, subfreezing winds exceeding $4.5 \mathrm{~m} \cdot \mathrm{s}^{-1}$ are expected. However, there are several cultural strategies, including double pruning of coldsensitive cultivars, that help to avoid or sprinkling for evaporative cooling at any one time).

4. The system can potentially be used in radiational frost conditions.

A poorly understood "natural protection" phenomenon that may occur under the dry atmospheric conditions associated with an advective freeze, frost/freeze, and black frost is a plant process known as supercooling. Recently, Spayd (2007) has reported, "...vines at similar growth stages in a vineyard that reportedly dropped to $-4.4{ }^{\circ} \mathrm{C}$ survived." This comment referred to an early Apr. 2007 (Easter) advective freeze in the Piedmont, foothills, and mountains of North Carolina, in which "all actively growing shoots (of Chardonnay) were killed when temperatures fell below $-5.0{ }^{\circ} \mathrm{C} "$ (Spayd, 2007).

However, researchers in New Zealand indicated that "Wind induced motion by buds or shoots can reduce supercooling by the agitation and result in freezing events at warmer temperatures" (Trought et al., 1999). This latter observation is difficult to reconcile with reports of how vines supercooled under advective conditions in North Carolina (Spayd, 2007).

Finally, it is important a grower to be aware that current methods for predicting wind speeds coupled with varying terrain in mountain areas can limit the reliability of weather forecasts for wind speeds. Also, keep in mind that wind speed forecasts are for $10 \mathrm{~m}$ aloft and not for the ground or vineyard level. For these reasons, wind speed forecasts are arguably the "weakest link" in the decision tree for event diagnosis (Fig. 4). The only practical solution to this problem is that the grower must monitor the vineyard closely on nights when a freeze or frost/freeze is predicted. As often happens, winds may suddenly die down during the night and then you find yourself dealing with a radiational cooling event.

2. Frost/freeze events. By definition, a frost/freeze will have sustained winds in excess of $2.2 \mathrm{~m} \cdot \mathrm{s}^{-1}$ but less than $4.5 \mathrm{~m} \cdot \mathrm{s}^{-1}$, which makes this a "protectable event" for overvine sprinkling, but for no other active methods shown in Table 4. A key principle to understand with this technique is that the sprinkler system will act as a "heating" system as long as the heat released by water freezing (called the latent heat of fusion) is keeping young grape shoots in a temperature range of -0.27 to $0{ }^{\circ} \mathrm{C}$ (Sugar et al., 2003). Latent heat of fusion ( $\mathrm{Lf}$ ) refers to the heat lost or gained by the air when liquid water changes to ice or vice versa. $\mathrm{Lf}=333$ Joules per gram $(\mathrm{J} / \mathrm{g})$ of water. Cold injury may occur if plant tissue temperatures are allowed to dip below the critical damaging temperature of $-0.55^{\circ} \mathrm{C}$ (Sugar et al., 2003). However, relatively high sprinkling rates are required under windy compared with calm wind conditions and this is needed both to supply heat to warm the vineyard as well as to satisfy heat losses through evaporation. Sprinkling systems can easily become "refrigeration systems" 
(Evans, 2000). If not enough heat is being generated by water freezing to offset evaporative cooling heat losses (latent heat of vaporization), crop damage can be actually be much worse than if no protection had been used. Latent heat of vaporization (Lv) refers to the heat lost by the air when liquid water changes into vapor. This is also commonly known as the latent heat of evaporation. $\mathrm{Lv}=$ -2500 Joules per gram $(\mathrm{J} / \mathrm{g})$ of water. Because the heat taken up by evaporation at $0{ }^{\circ} \mathrm{C}$ (latent heat of vaporization) is $\approx 7.5$ times as much as the heat released by freezing (latent heat of fusion), at least 7.5 times as much water must freeze as is evaporated (Perry, 1998). Obviously, this can lead to very high precipitation rates under cold, windy conditions. Evans reports that in colder areas such as the Pacific Northwest, adequate precipitation levels of protection require from 3.8 to $4.6 \mathrm{~mm} \cdot \mathrm{h}$ (2000). However, in North Carolina, the author has observed frost/freeze conditions in which at least $6.4 \mathrm{~mm} \cdot \mathrm{h}$ is required to offset evaporative cooling heat loss. An irrigation dealer can furnish charts that indicate appropriate precipitation rates for varying lowtemperature and wind speed combinations. With sprinkler irrigation for frost protection in vineyards, the system must be designed for worst-case conditions and be able to provide three consecutive frost/freeze nights of protection $(\approx 960,000 \mathrm{~L}$ of water/ha).

Another very critical point to understand with overvine sprinkling, whether it is being used in managing a frost/freeze or a black frost, involves using a wet bulb temperature of $-0.55{ }^{\circ} \mathrm{C}$ to guide your "start-up" decision time. Wet bulb temperature is a measurement of the evaporative cooling power of the air and can be measured using a sling psychrometer. Under conditions favoring evaporative cooling (either winds in a frost/freeze or the low humidity of a black frost), it is very important to turn on the sprinklers on the basis of wet bulb temperatures and not ambient temperatures (these two temperatures can be several degrees Celsius apart). Wet bulb temperature is a measurement of the evaporative cooling power of the air and can be measured using a sling psychrometer, an instrument composed of two thermometers, or by consulting the hourly wet bulb temperatures provided by an Internet weather forecast service for your area and vineyard(s). Both methods can be used to improve forecasting accuracy.

By using the wet bulb temperature, you will avoid what is referred to as an "evaporative dip" or "cold jolt" (Harker, 2006) resulting from evaporative cooling of the sprinkler drops when the system is first turned on. This 15- or 20-min dip can push temperatures of the grape tissues below their critical point and can cause serious cold injury.

Once sprinkling starts and an ice coat has built up, the system must operate continuously through the night. Water should slowly but continuously drip from the vine when the sprinkling system is working properly (Evans, 2000). The application rate is not sufficient if the ice has a milky color (from occlusion); ice should be clear at all times. Be especially cautious about stopping the application of water during the night if the temperature rises because of a light breeze or a few clouds. Once the breeze falls or the clouds disappear, the temperature will probably drop rapidly again.

Operate continuously after sun-up until you can see free water running between the ice and the grape buds and shoots or until ice falls easily from the vine structures (spurs, cordons). It is not necessary to run until all the ice has melted after the warm sunlight "takes over" (Ballard and Proebsting, 1981). However, if the morning should turn cloudy after sunrise, if there are chilly winds, or if both clouds and winds occur, continue to run the irrigation until the wet bulb temperature is above $-0.55{ }^{\circ} \mathrm{C}$ in the coldest portion of the vineyard.

3. Hoar frost (white frost). Essentially, a forecast for DP temperatures near or above the freezing point $\left(-2.2\right.$ to $\left.+2.2{ }^{\circ} \mathrm{C}\right)$ indicates that the lower atmosphere is relatively moist, and you need to pay very close attention to the start of "ice crystal" formation on plant tissues. Even if the DP is above the grape shoot critical temperature (e.g., $-0.55^{\circ} \mathrm{C}$; Sugar et al., 2003), you must still be concerned about the potential for injury from "ice crystals." Why is it so important to start up protection when you see ice crystals forming on the plant surface? The answer to this question came at a very recent symposium (Small Fruit and Grape Cold Injury Across the U.S. from the Historic Freeze in Apr. 2007, ASHS Annual Conference, Scottsdale, AZ, 16 July 2007) when a USDA-ARS scientist showed, using infrared thermography to study freezing in plants, that any surface moisture, including ice crystals, can serve as an important extrinsic agent on the plant surface (Wisniewski, 2007) along with Ice-Nucleic Active (INA) bacteria (Lindemann and Suslow, 1987). Surface nucleators may trigger ice formation inside plant tissues, and according to Evans (2000), "whenever ice forms in the plant tissue, there will be damage regardless of how long it took to reach that point."

It is impossible to predict whether a hoar frost will injure sensitive grape tissues, and that is why hoar frost protection with wind machines (Fig. 5), heaters, helicopters, and overvine sprinkling should be initiated at the first appearance of frost ice crystals (Poling, 2007a)

Wind machine operation. As soon as you detect any frost forming on exposed grape plant tissues, turn the wind machine on. By stirring up the air, wind machines can interfere with ice crystal formation.

Monitor air temperatures after sunrise, and continue to run the wind machine until the temperature is above $0{ }^{\circ} \mathrm{C}$ in the lowest area of the vineyard.

4. Dew point temperatures slightly below the critical temperature. Under a radiational cooling scenario with DP temperatures in the range of -2.7 to $-1.1{ }^{\circ} \mathrm{C}$, which may be slightly below a "critical temperature" for a young grape shoot of $-0.55^{\circ} \mathrm{C}$ (Sugar et al., 2003), it is recommended that the grower start wind machine protection when thermometers in the coldest spots in the vineyard have dropped into the range of 0 to $1.1{ }^{\circ} \mathrm{C}$ (Evans, 2000). It is not recommended that the grower start protection at air temperatures that are

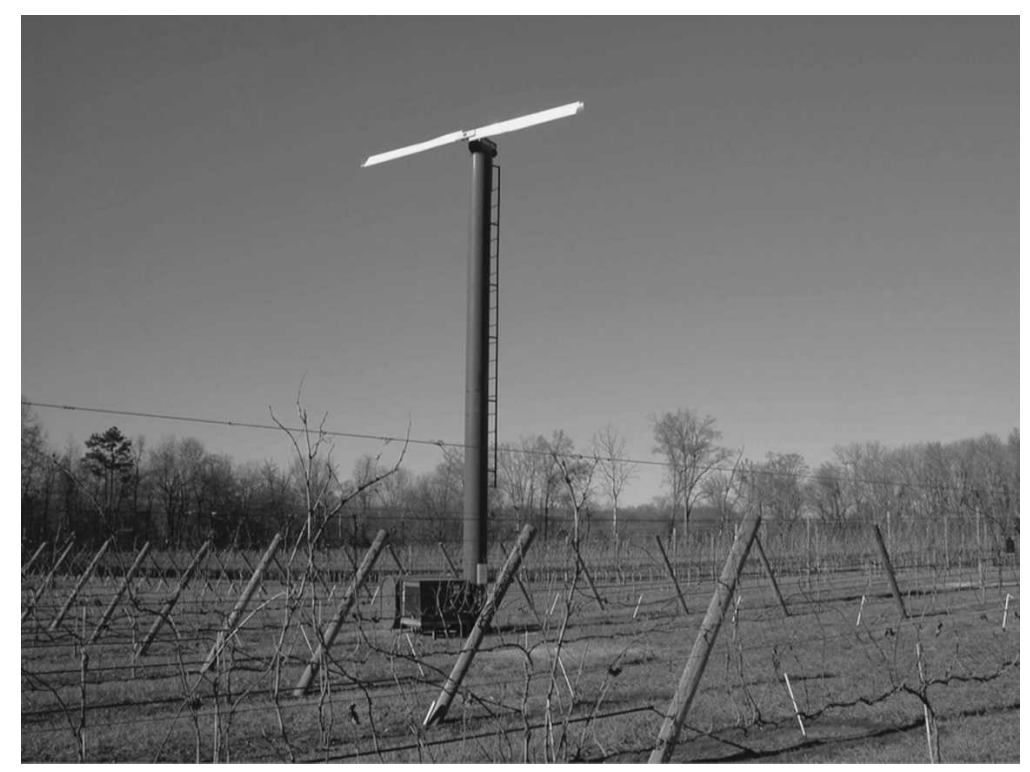

Fig. 5. This Orchard-Rite, Ltd. (Yakima, WA) wind machine stands $10.7 \mathrm{~m}$ above the vineyard floor and has a gas-powered engine that turns a $5.8-\mathrm{m}$ fan. It protects a 2.83 -ha vineyard in Davidson County, NC. The fans or propellers minimize cold air stratification in the vineyard and bring in warmer air from the thermal inversion. The amount of protection or temperature increase in the orchard depends on several factors. However, as a general rule, the maximum that the air temperature can be increased is $\approx 50 \%$ of the temperature difference (thermal inversion strength) between the 1.8- and 15.2-m levels. Thus, these machines are generally not very effective with minimum temperatures below $-2.2{ }^{\circ} \mathrm{C}$. (Photo by Barclay Poling, 18 Dec. 2005.) 
slightly below $0{ }^{\circ} \mathrm{C}\left(\right.$ e.g., $\left.-0.55^{\circ}\right)$, because the crop temperature may have already reached a critical temperature threshold of perhaps $-0.55{ }^{\circ} \mathrm{C}$ before this time, especially with a DP temperature closer to $-2.7^{\circ} \mathrm{C}$. With an overvine sprinkling system, follow the recommendation of starting at a wet bulb temperature of $-0.55^{\circ} \mathrm{C}$ or slightly higher (same as for black frost and frost/freeze).

5. Black frost events. Black frosts are perhaps the most challenging type of cold event to manage at the postbudbreak stages of development for several reasons. First, greater heating capacity is required for successful crop protection in a black frost than in a hoar frost. A wind machine alone is not likely to provide enough heating, and using a helicopter service to supplement wind machine protection may be a profitable decision for a very high value $V$. vinifera cultivar such as 'Chardonnay', which could be badly damaged if temperatures in the vineyard do drop below $-2.2{ }^{\circ} \mathrm{C}$ (Wolf and Poling, 1995).

Black frosts can also seriously fool the grower who depends on seeing evidence of ice crystals as a basis for starting countermeasures. If the DP is $-3.8^{\circ} \mathrm{C}$, for example, you will not be able to see (or feel) any frost forming on the plant surface until the air temperature reaches its dew point, or frost point (Perry, 1998), of $-3.8^{\circ} \mathrm{C}$. By delaying protection until frost is finally observed at $-3.8^{\circ} \mathrm{C}$, it could be too late because the frost point of $-3.8^{\circ} \mathrm{C}$ is likely below the "critical temperature" for an expanding grape shoot, which is believed to be in the range of just below 0 to $-2.2^{\circ} \mathrm{C}$ (Dami, 2007; Sugar et al., 2003; Trought et al., 1999, Wolf and Poling, 1995). Obviously, a grower does not want to start countermeasures when the crop temperature is below its critical temperature. At the present time, there is no practical method for grape growers to determine whether supercooling of grape shoots is possibly occurring under the dry atmospheric conditions associated with a black frost (Wolf and Boyer, 2003). Better scientific understanding of critical temperatures of grape shoots under dry atmospheric conditions would be of great practical benefit to grape growers who currently operate on the basis of starting up active protection systems before shoot tissues in developing grape reach 0 to $-0.55^{\circ} \mathrm{C}$.

A third confusing aspect of a black frost has to do with the fact that in the dry atmospheric conditions, air temperatures may be 2 to $3{ }^{\circ} \mathrm{C}$ warmer than the actual crop temperature (Evans, 2000).

Practical rules to follow in a black frost.

1. Make sure that you provide enough heating (through active protection) to keep tender shoots and expanding grape buds above their critical temperature of $-0.55^{\circ} \mathrm{C}$ at all times, including startup.

2. Never wait for the appearance of "frost crystals" to start protection.
3. Be sure to use a "safety factor" that adjusts for the difference between the air temperature and crop temperature.

For wind machines, the exact startup air temperature for cold protection will depend on the dryness of the lower atmosphere as indicated by DP temperature. Consult Table 5 for the "safety factors" recommended by Evans (2000).

An important guideline with sprinkling under black frost conditions is to turn on the sprinklers on the basis of wet bulb temperatures and not the air temperature. By beginning overvine irrigation at a wet bulb temperature of $-0.55{ }^{\circ} \mathrm{C}$, or slightly higher, you will prevent tender shoots from experiencing a "cold jolt" at startup.

A method that has the advantage of eliminating all the inconvenience of having to consult DP temperatures (or wet bulb temperatures) is to consider using thermocouples to make startup (and shutdown) decisions in a black frost. These are temperature measurement devices small enough to be inserted into plant tissues such as a strawberry bud or blossom. These devices could also be used to directly measure the temperature of a young grape shoot. A digital thermometer is connected to the thermocouple to get a readout of the plant temperature (Perry, 1998). These relatively inexpensive plant temperature sensors give the strawberry growers much greater confidence in deciding when to begin protection measures in strawberries under dry atmospheric conditions. They could be of similar benefit to grape growers for black frost and frost/freeze protection.

\section{CONCLUSION}

Winegrape growers are eager to know of better strategies and methods to control injury in the postbudbreak period from spring season radiational frost, frost/freeze, and freeze events. Historically, growers in eastern and midwestern continental climate regions of the United States have relied primarily on passive control of spring frost events by selecting sites in inland areas that are above a valley floor in hilly and mountainous terrain with favorable air drainage characteristics. Today, however, premium $V$. vinifera cultivars are also being grown in lower-elevation areas (e.g., the Piedmont area of North Carolina and Virginia), where there is a higher probability of radiational frost injury after budbreak. For vineyards in higher-risk areas for frost, growers need to have access to economical and reliable methods of active frost control to supplement passive control methods. An investment in an "active" frost protection system may be justified in vineyard regions and locations that are relatively frost-prone. In using an economic investment analysis, we demonstrated that for vineyard sites with a probability of radiational frost in 2 of 10 years, a wind machine could be a profitable risk management tool.

Wind machines have the advantages of being effective in preventing damage from hoar (white) frost and they are relatively simple to manage and operate. The grower does not need to worry about using wet bulb temperatures or evaporative cooling issues (as is the case with overvine irrigation). However, growers are advised to be proactive in their use of wind machines or any other protection method (overvine sprinklers, heaters, and helicopters) in preventing ice crystal formation associated with a hoar frost. Once ice forms in the plant tissue, there will be damage. USDA-ARS scientists have shown using infrared thermography that any surface moisture, including ice crystals, can serve as an important extrinsic agent on the plant surface (Wisniewski, 2007).

Advance weather forecasts from a subscription service can provide information on DP temperatures, which can help the grower assess whether he or she may be dealing with a hoar frost (relatively high DP) or black frost (relatively low DP). When the DP is below the critical temperature of $-0.55{ }^{\circ} \mathrm{C}$, expect that plant tissue temperatures will fall more rapidly than the surrounding air temperature, and the amount of upward adjustment in the startup air temperature will be related to the dryness of the lower atmosphere as indicated by DP temperature. Thus, in dry atmospheric radiation frost conditions, be conscious of the need to monitor both vineyard air temperature and humidity (using DP temperature).

The grower must also be conscious of the real limits of wind machines in situations that have the potential for black frost. Likewise, wind machines cannot be successfully deployed in a frost/freeze or freeze. There is no place for "unfounded optimism" when trying to match wind machines to these more severe cold events.

Opportunities to use sprinkler irrigation for controlling more severe types of cold events in the postbudbreak period have also been addressed in this article. Overhead sprinkling for frost and frost/freeze protection has been most successful on low-growing crops

Table 5. Using dew point (DP) temperatures to determine startup air temperatures in frost protection ${ }^{\mathrm{z}}$.

If the DP is in the range of:

a) $-10{ }^{\circ} \mathrm{C}$ to $-7{ }^{\circ} \mathrm{C}$

c) $-3{ }^{\circ} \mathrm{C}$ to $-1.7^{\circ} \mathrm{C}$

Start frost equipment when air temperature is $\approx 1.7$ to $2.7^{\circ} \mathrm{C}$

Start frost equipment when air temperature is $\approx 1.1^{\circ} \mathrm{C}$

Start frost equipment when air temperature is $\approx 0{ }^{\circ} \mathrm{C}$ to $0.5^{\circ} \mathrm{C}^{z}$

${ }^{\mathrm{z} E s s e n t i a l l y, ~ a ~ f o r e c a s t ~ o f ~ D P ~ t e m p e r a t u r e s ~ n e a r ~ o r ~ a b o v e ~} 0^{\circ} \mathrm{C}$ indicates that the lower atmosphere is fairly moist, and the grower will need to pay very close attention to the start of ice crystal formation on plant tissues as the basis for starting up frost protection measures. 
such as strawberries (Pair et al., 1975). Overvine sprinkling has been used in grapes (Jackson, 2000; Poling, 2007a; Trought et al., 1999); however, these systems require very careful design and considerable operator knowledge and skill to avoid more damage to the crop than would have occurred if protection had not been attempted (Pair et al., 1975).

The author would also argue that winegrape growers using overvine sprinkling will need considerable input from the NWS, various state and local weather service providers, and their respective state Extension viticulturists as far as making the most effective use of sprinkler irrigation technology. The strawberry plasticulture industry in North Carolina, for example, receives timely seasonal alerts about threatening cold events in an electronic advisory called berry $\mathrm{mg}$, and this has been very important to grower decision-making in dealing with complex weather scenarios such as the Easter freeze of 2007 (Poling, 2007b).

Finally, recent winter and spring freezes in the eastern and midwestern United States have proven to be very costly to the winegrape industry (Warmund and Guinan, 2007; Zabadal et al., 2007). Some have argued that the Easter freeze of 2007 should not be viewed as an isolated event (ENS, 2007). Rather, it represents a climate change scenario of milder winters and warm, early springs. It is concerning that the findings of a northeastern research team (Wolfe et al., 2005) document that there has been a 2- to 8$\mathrm{d}$ shift in the spring phenology of three horticultural woody perennials most concerning to realize that in the northeastern United States (including lilac, apple, and grape) for the period 1965 to 2001 .

At the minimum, we need to be having more conversations about the potential connection between a global warming trend and grape phenology shifts. If we consider the impact of just a 1-week shift in the phenology calendar of 'Chardonnay' in our research vineyard in Reidsville, NC, the probability of a damaging frost event in the third week of April (15 to 21 Apr.) is $21.0 \%$ for an emerged shoot $(2.54$ to $5.08 \mathrm{~cm})$ with a critical temperature threshold of just below $0{ }^{\circ} \mathrm{C}$ (Table 2). In this scenario, an investment in a wind machine is attractive (Table 3 ). An advance in the grape phenology calendar of just 1 week could result in a significantly elevated risk of damaging cold events for most vineyards in the eastern and midwest regions of the United States. Global warming may be contributing to a scenario in the future where earlier than normal budbreak is normal.

There is no better time than the present to more fully examine the implications of climate change (Furer, 2006; Intergovernmental Panel on Climate Change, 2007; Wolf, 2007; Oak Ridge National Laboratory, 2007) for the future cold protection needs of eastern and midwestern winegrape growers as has been done at a recent grower workshop sponsored by the Institute for Continental
Climate Viticulture and Enology in Columbia, MO (5 to 7 Dec. 2007) and at the ASHS Annual Conference Symposium: Small Fruit and Grape Crop Injury Across the U.S. from the Historic Freeze in Apr. 2007 (Scottsdale, AZ, 16 July 2007).

\section{Literature Cited}

Ballard, J.K. and E.L. Proebsting. 1981. Frost and frost control in Washington orchards. Washington State University Coop. Ext., Pullman, Ext. Bul. 634

Dami, I. 2007. Delaying grapevine bud burst with oils. In: Proc. Inst. for Continental Climate Viticulture and Enology-Understanding and preventing freeze damage in vineyards, University of Missouri-Columbia, 5-6 Dec. p. 89-93.

Dami, I., B. Bordelon, D.C. Ferree, M. Brown, M.E. Ellis, R.N. Williams, and D. Doohan. 2005. Midwest grape production guide. Ohio State University, Bul. 919, p. 15.

ENS. 2007. Easter freeze 2007 showed paradox of climate change. 10 June 2008. <http://www.envir onmentalexpert.com/resultEachArticle.aspx? cid $=29046 \&$ codi $=29663$ \&idproducttype $=6>$.

Evans, R.G. 2000. The art of protecting grapevines from low temperature injury. Proc. ASEV 50th Anniversary Annual Mtg., Seattle WA, 19-23 June. p. 60-72.

Food and Agriculture Organization of the United Nations. 2005. Frost protection: Fundamentals, practice and economics. Vol. 1. p. 2.

Fraser, H., K. Silngerland, K. Ker, H. Fisher, and R. Brewster. 2008. Wind machines for minimizing cold injury. InfoSheet Ontario Ministry of Agriculture, Food and Rural Affairs.

Furer, D. 2006. Why the wine industry should care about global warming? Wine Business Monthly. 15 July 2006. <http://www.winebusiness.com/GrapeGrowing/webarticle.cfm?dataId= 43868>.

Gardea, A.A. 1987. Freeze damage of 'Pinot noir' (Vitis vinifera L.) as affected by bud development, INA bacteria, and bacterial inhibitor, Oregon State University, Corvallis. MS Thesis.

Harker, K. 2006. Wet bulb temperature-What it is and how to use it. AWIS Freeze/Frost Fact Sheets. 10 June 2008. <http://www.awis.com/ Misc/Fact_Sheets.htm\#Wet>.

Howell, G.S. 1998. Michigan grapes. 10 June 2008. $<$ http://weblmsue.msu.edu/fruit/grpfrost.htm>.

Hurt, W.N. 1923. Thermal belts and fruit growing in North Carolina. U.S. Dept. of Agriculture's Monthly Weather Review Suppl., No. 19.

Intergovernmental Panel on Climate Change. 2007. Climate change 2007: Synthesis report. 10 June 2008. <http://www.energybulletin.net/37355. html>

Jackson, R.S. 2000. Site selection and climate, Chapter 5, p. 219-220. In: Wine sciencePrinciples, practices, perception. Academic Press, San Diego, CA.

Johnson, D.E. and G.S. Howell. 1981. Factors influencing critical temperature for spring freeze damage to developing primary shoots of Concord grapevines. Amer. J. Enol. Viticult. $32: 144-149$

Ker, K. 2007. Ontario's experience with wind machines for winter injury protection of grapevines and tender fruit. In: Proc. of Inst. for Continental Climate Viticulture and EnologyUnderstanding and preventing freeze damage in vineyards, University of Missouri-Columbia, 5-6 Dec. p. 75-78.

Lindemann, J. and T.V. Suslow. 1987. Competition between ice nucleation-active wild type and ice-nucleation-deficient deletion mutant strains of Pseudomonas syringae and P. fluorescens Biovar 1 and biological control of frost injury on strawberry blossoms. Phytopathology 77:882-886.

Moncur, M.W., K. Rattigan, D.H. McKenzie, and G.N. McIntyre. 1989. Base temperatures for budbreak and leaf appearance of grapevines. Amer. J. Enol. Viticult. 40:21-26.

Oak Ridge National Laboratory. 2007. Life in a warmer land. Oak Ridge Natl. Lab. Rev. 40: $18-19$.

Pair, C.H., W.W. Hinz, C. Reid, and K.R. Frost. 1975. Sprinkler irrigation. Irr. Assn., Silver Spring, MD. p. 384-387.

Perry, K.B. 1994. Frost protection: Fundamentals, practice, and economics. Vol. 1. FAO Corporate Document Repository. 10 June 2008. $<$ http://www.fao.org/docrep/008/y7223e/ y7223e07.htm>

Perry, K.B. 1998. Basics of frost and freeze protection for horticultural grapes. HortTechnology 8:10-15.

Perry, K.B. 2001. Frost/freeze protection for horticultural crops. Hort. Info. Lflt. 705, North Carolina Coop. Ext. Serv., NC State University, Raleigh.

Poling, E.B. 2007a. Spring frost control, Chapter 11, p. 159-175. In: North Carolina winegrape grower's guide (AG-535). North Carolina Coop. Ext. Serv., NC State University, Raleigh.

Poling, E.B. 2007b. Crop decision support tools and specific cold protection techniques used in North Carolina to minimize injury to the strawberry crop. HortScience 42:795. (abstr.).

Pool, R. 1997. Continentality in relation to vineyard site selection. 10 June 2008. <http://www.nysaes. cornell.edu/hort/faculty/pool/NYSite-Soils/ continentality.html $>$.

Proebsting, E.L. 1978. Deciduous fruit freeze survival, p. 273. In: Li, P.H. and A. Sakai (eds.). Plant cold hardiness and freezing stress. Academic Press, New York, NY

Snyder, R.L. 2001. Principles of frost protection. Atmospheric Science, University of California, Davis. 10 June 2008. <http://biometucdavis. edu/frostprotection/Principles $\% 20$ of $\% 20$ Frost $\%$ 20Protection/FP005.html $>$.

Spayd, S.E. 2007. Wine-grape cold injury assessment in post-budbreak period. HortScience 42:795-796. (abstr.).

Sproull, R. 2006. Black frosts wipe $\$ 100 \mathrm{~m}$ off next year's vintage. Austral. News. 1 Nov. 2006. $<$ http://wwwpropeller.com/viewstory/2006/10/ 31/black-frosts-damage-aussie-grapes/?url=http $\% 3 \mathrm{~A} \% 2 \mathrm{~F} \% 2 \mathrm{Fwww}$.theaustralian.news.com.au $\%$ 2Fstory\%2F0\%2C20867\%2C20680475-30417\% $2 \mathrm{C} 00$. html\& frame $=$ true $>$.

Striegler, R.K. 2007. Passive freeze prevention methods, p. 39-46. In: Proc. Inst. for Continental Climate Viticulture and EnologyUnderstanding and preventing freeze damage in vineyards. University of Missouri-Columbia, 5-6 Dec.

Sugar, D., R. Gold, P. Lombard, and A. Gardea. 2003. Strategies for frost protection, p. 213-217. In: Hellman, E.W. (ed.). Oregon viticulture, strategies for frost protection. Oregon State University, Corvallis.

Trought, M.C.T., G.S. Howell, and N. Cherry. 1999. Practical considerations for reducing frost damage in vineyards. Lincoln University, New Zealand.

Warmund, M. and P. Guinan. 2007. Temperature and cold damage assessment across the eastern U.S. associated with the Apr. 2007 freeze. HortScience 42:795. (abstr.).

Westwood, M.N. 1978. Temperate-zone pomology. Freeman, San Francisco, CA. p. 319. 
Wisniewski, M. 2007. Using infrared thermography to study freezing in plants. HortScience 42:795. (abstr.).

Wolf, R. 2007. Easter freeze of Apr. 2007: A climatological perspective and assessment of impacts and services. NOAA/ USDA Tech. Rpt. 2008-01. 10 June 2008. $<$ http://olsnndc.noaa.gov/plolstore/plsql/ olstore.prodspecific?prodnum $=$ C00712-PUBA0001>.
Wolf, T.K. and J.D. Boyer. 2003. Vineyard site selection. Virginia Polytechnic Inst. and State University, Blacksburg. Publ. No. 463-020. 10 June 2008. <http://www. ext.vt.edu/pubs/viticulture/463-020/463-020. html>.

Wolf, T.K. and E.B. Poling. 1995. The midAtlantic winegrape grower's guide (AG-535). North Carolina Coop. Ext. Serv., NC State University, Raleigh.
Wolfe, D.W., M.D. Schwartz, A.N. Lakso, Y. Otsuki, R.M. Pool, and N.J. Shaulis. 2005. Int. J. Biometeorol. 49:303-309.

Wooing Tree Vineyard. 2008. About central Ontago. 10 June 2008. <http://www.wooingtree. co.nz/about_central_otago.html $>$.

Zabadal, T.J., I.E. Dami, M.C. Goffinet, T.E. Martinson, and M.L. Chien. 2007. Winter injury to grapevines and methods of protection. Ext. Bul. E2930. Michigan State University. 